\title{
The Impact of Technological Innovation on China's Economic Level
}

\author{
Yue Shan \\ College of Science, Northeastern University, Boston 02115, USA \\ ys.shan@outlook.com
}

\begin{abstract}
Based on the Cobb-Douglas production function, this paper studies the impact of China's domestic technological innovation on China's economic level from 1992 to 2016. Considering the lag of the impact of technological innovation on economic level, this paper input the time series data into the Cobb-Douglas production function to establish an autoregression model (AR). Firstly, it uses the ADF to verify whether the variables have a unit root, and then uses the regression models to analyze the impact of technological innovation, number of research and development (R\&D) personnel, and capital investment on China's gross domestic product (GDP). Through the empirical analysis, it can be concluded that the GDP lagging one year, the domestic patent granted lagging one year, the total investment in fixed assets and the total investment in fixed assets lagging one year do have a positive contribution to the economic level. However, the R\&D personnel full-time equivalent and the R\&D personnel full-time equivalent lagging one year are negatively related to the economic level, which implies that there might be excessive R\&D personnel full-time equivalent in China. There are two explanations to answer why the economic level goes down when we add more researchers into labor market. For one thing, researchers in China are not able to efficiently transform their research into technological innovation. For another, China's current economic level and market share limit its ability to benefit from increasing R\&D personnel full-time equivalent.
\end{abstract}

Keywords: technological innovation, economic level, AR.

\section{Introduction}

Since 1992, China's economy has developed rapidly. The per capita GDP in China has increased from 2,334 yuan in 1992 to 53,980 yuan in 2016. At the same time, China's GDP has increased by around 26 times from 271.045 million yuan to 74412.72 billion yuan, which largely benefited from the demographic dividend. However, because of the family planning policy, China is increasingly confronted with the aging problem and thus the shrinking labor force. According to production function, one of the famous concepts of mainstream neoclassical, production is affected by land, labor, capital, and entrepreneurial talent. If only these factors could promote the development of the economic level, China's economic level would definitely decline accompanied with less and less labor in the future. However, "Solow Residual" proposed by Solow refers to the output growth coming from total factor productivity except for constant contributions by land, labor and capital investment. The total factor productivity, an indicator used measure productivity, indicates the "residual" increase in output due to technology growth. Thus, the level of scientific and technological development also positively affects productivity, and then influences the economic level. Chinese policy makers need to figure out how to accelerate technology growth to remedy imminent reduction of labor force. When the day of the labor force has slumped is coming, the development of China's economic level will still have possibility and space for sustainable growth.

From 1992 to 2016, the development of China's economic level was inseparable from the factors of labor and capital investment. In addition, according to Solow Residual, huge growth of China's GDP is also impacted by development of science and technology. From the China Statistical Yearbook on Science and Technology, the domestic patent granted increased from 28,311 in 1992 to $1,620,881$ in 2016, an increase of 56.5 times during this period. And in 1992, the R\&D personnel full-time equivalent was about 0.67 million, accounting for only $0.1 \%$ of the total labor force in China (662 million). The data of 2016 showed that the R\&D personnel full-time equivalent was about 3.88 million, accounting for $0.5 \%$ of the total labor force in China (776 million). In the past 25 years, the Chinese labor force has increased by $17.2 \%$, while the R\&D personnel full-time equivalent have 
jumped by about $480 \%$. The question is whether such amazing growth of R\&D personnel full-time equivalent and technological innovation ability means that China's economic level will continue to develop rapidly. When the future labor force decreases year by year and the level of national education increases, the R\&D personnel full-time equivalent will continually increase and will account for a higher proportion in labor force. Thus, improving and utilizing technology in production is the one of the best ways for China to achieve sustainable development of economic level in the future.

\section{Literature Review and Hypothesis}

In 1994, Grossman and Helpman's model proposed that innovation is the best opportunity to overcome economic growth constraints and the driving force for long-term economic development [1]. During the period of 1992 to 2000, based on time trend and general index model, Oh and Heshmati conducted the research of what role technical changes and TFP growth played in Swedish economy productivity which has grown from the weakest to the strongest in Organization for Economic Co-operation and Development (OECD). Their research disclosed the main mechanism of the development - the incremental rate of technical change drove the whole Swedish economy going up [2], which demonstrates that if a country with backward economic level wants to develop to a powerful one with high productivity, an important strategy is increasing its rate of technical change. Based on the empirical results of the panel vector auto-regression model in 2016, Pradhan and Arvin found that the ability of the Eurozone economies on incremental innovation scale determines longterm economic growth in order to maintain its global competitiveness. This also requires allocating sufficient resources for R\&D activities to drive the key economic components of these countries [3]. It indicated that the scale of innovation and the sufficient distribution of innovation resources are also one of the influencing factors to the long-term stable growth for Chinese economy.

In 2007, according to non-scale endogenous growth theory, Ulku studied developed and developing countries and found that increasing the proportion of researchers in the labor force would increase innovation capability. Moreover, after increasing the innovation capability, per capita output could be further increased. It has been found that increasing the number of researchers and having a positive impact on innovation capabilities will only occur in OECD countries which have large markets. In addition, it is precisely these OECD countries with large markets that are industrially developed with high per capita income and well-established institutions can support the R\&D sector and achieve high levels of technological innovation. [4]. Which explains that since China is currently in the position of a developing country, increasing the number of researchers does not necessarily have a positive effect on the technological innovation. Moreover, if China cannot absorb the benefit from inputting more researcher, more researchers could conversely drive down the economic level of China. In 2014, based on the Schumpeterian model, it was concluded that technological innovation had a positive effect on economic development, and that more entrepreneurial activities and technological innovations would increase economic activity and continue to positively influence entrepreneurial activities and technological innovation [5]. This shows that technological innovation has a certain lag impact of the development of economic level.

Based on previous studies by researchers, this paper proposes three hypotheses:

Hypothesis 1: There is a positive correlation between technological innovation and economic level, that is, the greater technological innovation, the better the economic level is.

Hypothesis 2: The increase in the R\&D personnel full-time equivalent will also affect the economic level. This effect may not be significant on the current economic level in China, or it might even reduce the GDP growth.

Hypothesis 3: There is a certain lag in the impact of technological innovation on the economic level. 


\section{Research Methods}

\subsection{Theoretical Models}

In the literature, on the relationship between technological innovation and economic growth, the assumption of the production function is very crucial. After Solow proposed "Solow Residual", economists from all over the world began to pay attention to the impact of technological development on the economic level. The Solow Residual refers to the increase in output brought about by total factor productivity, in addition to the contribution of labor and capital investment. The Solow-Swan model uses capital input and labor input as explanatory variables to establish a growth model of the Cobb-Douglas production function. The Solow-Swan model uses technological progress as an exogenous variable to explain economic growth. However, in the realistic economy, on the one hand, the technological innovation process will affect the labor input process, making the division of labor more professional and reasonable, and thus improve productivity. On the other hand, the process of capital accumulation also includes technological innovation processes such as R\&D activities, innovation and invention activities. In addition, the certain inertia in the process of economic growth also has constancy, that is, the economic level of the previous periods has a certain impact on the current economic development, and the effect of technological innovation on economic growth has a time lag. Based on this, this paper expands and modifies the Solow-Swan model, introduces time variables, and uses technological innovation as an endogenous variable. The Cobb-Douglas production function shows that the main factors determining the level of industrial development are labor input and capital input, as well as the total factor productivity (including management level, labor quality, introduction of advanced technology, etc.).

The following is the Cobb Douglas production function variant:

$$
Y_{t}=K_{t}^{\alpha} L_{t}^{\beta} P_{t}^{\gamma}
$$

Where $Y_{t}$ represents the economic level, $K_{t}$ represents the regional capital stock, $L_{t}$ represents the R\&D personnel input, and $P_{t}$ indicates the technological innovation capability. $\alpha, \beta$ and $\gamma$ represent the capital stock, the R\&D personnel input and the output contribution of technological innovation capability respectively, $\alpha+\beta+\gamma=1$

In order to avoid the problem of heteroscedasticity, we logarithmically linearize the above model to get the model:

$$
\ln Y_{t}=\alpha \ln K_{t}+\beta \ln L_{t}+\gamma \ln P_{t}+\varepsilon_{t}
$$

\subsection{Variable Selection, Data Source and Preprocessing}

This paper uses China's GDP to represent the economic level, and utilizes the consumer price index to adjust the GDP in 1978 as the base period to eliminate the impact of price changes. Since the purpose of this study is about the impact of technological innovation on economic development, in order to reduce the impact of other practitioners on the model, this paper uses the R\&D personnel full-time equivalent to represent labor input. Since technological innovation is a relatively abstract concept, the technological innovation capability in this paper is indicated by domestic patent granted. We choose the total investment in fixed assets to represent capital input.

The variables selected in this paper are GDP, total investment in fixed assets, R\&D personnel fulltime equivalent, and domestic patent granted. The data sources are all from the China Statistical Yearbook and the China Statistical Yearbook on Science and Technology. 
Table 1. Description of the main variables in this paper

\begin{tabular}{|c|c|c|c|}
\hline Variables & Indicator & $\begin{array}{c}\text { Variable } \\
\text { Type } \\
\text { Continuous } \\
\text { type }\end{array}$ & China Statistical Yearbook \\
\hline Regional capital stock & $\begin{array}{c}\text { Total investment in fixed } \\
\text { assets (million yuan) }\end{array}$ & $\begin{array}{c}\text { Continuous } \\
\text { type }\end{array}$ & China Statistical Yearbook \\
\hline R\&D personnel input & $\begin{array}{c}\text { R\&D personnel full-time } \\
\text { equivalent (person year) }\end{array}$ & $\begin{array}{c}\text { Continuous } \\
\text { type }\end{array}$ & $\begin{array}{c}\text { China Science and } \\
\text { Technology Statistical } \\
\text { Yearbook }\end{array}$ \\
\hline $\begin{array}{c}\text { Technological } \\
\text { innovation capability }\end{array}$ & Domestic patent granted & $\begin{array}{c}\text { Continuous } \\
\text { type }\end{array}$ & $\begin{array}{c}\text { China Science and } \\
\text { Technology Statistical } \\
\text { Yearbook }\end{array}$ \\
\hline
\end{tabular}

\section{Empirical Analysis}

\subsection{Descriptive Statistics}

The descriptive statistics of the main variables in this paper (see Table 2) are as follows: this paper uses the time series data of China for 25 years. When we consider the standard deviation of the data, the discreteness of the variables is large. If the original data is directly used for analysis, the heteroscedasticity issue will highly probable occur. Therefore, the data in this paper is processed first by logarithm before analysis. From the average, the maximum and the minimum values, it can be seen that the variables are basically showing a rising tendency. In other words, as the Chinese economy continues to grow, the R\&D personnel full-time equivalent, the total investment in fixed assets, and the domestic patent granted increase simultaneously every year.

Table 2. Descriptive statistics of variables

\begin{tabular}{|c|c|c|c|c|c|c|}
\hline Variables & Symbol & $\begin{array}{c}\text { Number of } \\
\text { samples }\end{array}$ & Average & $\begin{array}{c}\text { Standard } \\
\text { deviation }\end{array}$ & Maximum & Minimum \\
\hline GDP & $\mathrm{Y}$ & 25 & 263717.6 & 228986.4 & 744127.2 & 27194.5 \\
\hline $\begin{array}{c}\text { R\&D personnel full- } \\
\text { time equivalent }\end{array}$ & $\mathrm{L}$ & 25 & 174.8168 & 113.1074 & 387.81 & 67.43 \\
\hline $\begin{array}{c}\text { Total investment in } \\
\text { fixed assets }\end{array}$ & $\mathrm{K}$ & 25 & 169144.3 & 191469.6 & 606465.7 & 8080.1 \\
\hline $\begin{array}{c}\text { Domestic patent } \\
\text { granted }\end{array}$ & $\mathrm{P}$ & 25 & 440666.4 & 526388.8 & 1628881 & 28311 \\
\hline
\end{tabular}

\subsection{Stationarity Test}

Before conducting the cointegration analysis, it is necessary to check whether the variables are stationary. That is, before establishing the regression model, it is crucial to check whether the variables have a stationary time series relationship, in case of the existence of spurious regression and many other problems. This study uses the ADF test to examine the stationary of annual data. To be specific, we adopt the model $\ln Y_{t}=\alpha \ln K_{t}+\beta \ln L_{t}+\gamma \ln P_{t}+\varepsilon_{t}$ to conduct the unit square root test on $\operatorname{lnGDP}$, lnPatent, lnCapital, lnLabor and their first-order difference. The results of the stationarity test are shown in Table 3. 
Table 3. Results of ADF test

\begin{tabular}{|c|c|c|c|c|c|c|}
\hline Variable & $\begin{array}{c}\text { ADF } \\
\text { test }\end{array}$ & $\begin{array}{c}\text { Test type } \\
(\mathrm{c}, \mathrm{t}, \mathrm{k})\end{array}$ & $\begin{array}{c}1 \% \text { Critical } \\
\text { Value }\end{array}$ & $\begin{array}{c}5 \% \text { Critical } \\
\text { Value }\end{array}$ & $\begin{array}{c}10 \% \text { Critical } \\
\text { Value }\end{array}$ & $\begin{array}{c}\text { Stationary or Non- } \\
\text { stationary }\end{array}$ \\
\hline lnGDP & -2.801 & $(\mathrm{c}, 0,0)$ & -2.508 & -1.717 & -1.321 & Stationary \\
\hline InCaptital & -3.026 & $(0, \mathrm{t}, 1)$ & -4.380 & -3.600 & -3.240 & Non- stationary \\
\hline $\ln$ Labor & -1.812 & $(0, \mathrm{t}, 1)$ & -4.380 & -3.600 & -3.240 & Non- stationary \\
\hline $\ln$ Patent & -3.840 & $(0, \mathrm{t}, 1)$ & -4.380 & -3.600 & -3.240 & Non- stationary \\
\hline
\end{tabular}

Notes: a. In the stationarity test, $\mathrm{t}(\mathrm{c}, \mathrm{t}, \mathrm{k})$ represents the type of test, where $\mathrm{c}$ and $\mathrm{t}$ respectively represent the intercept term and the time trend, and $\mathrm{k}$ indicates the order of the lag; $\mathrm{b}$. The ADF test is implemented by STaTa14 software; c. The null hypothesis H0: The time series of this variable has a unit root.

Based on the ADF, we can conclude lnGDP is stationary, while lnCapital, lnLabor, and lnPatent are unstable. Next, we use the ADF to test their first-order difference variables. The results are shown in Table 4.

Table 4. ADF test of order 1

\begin{tabular}{|c|c|c|c|c|c|c|}
\hline Variable & $\begin{array}{c}\text { ADF test } \\
\text { value }\end{array}$ & $\begin{array}{c}\text { Test type } \\
(\mathrm{c}, \mathrm{t}, \mathrm{k})\end{array}$ & $\begin{array}{c}1 \% \text { Critical } \\
\text { Value }\end{array}$ & $\begin{array}{c}5 \% \text { Critical } \\
\text { Value }\end{array}$ & $\begin{array}{c}10 \% \\
\text { Critical } \\
\text { Value }\end{array}$ & $\begin{array}{c}\text { Stationary or } \\
\text { Non-stationary }\end{array}$ \\
\hline dlnGDP & -3.857 & $(0,0,1)$ & -3.750 & -3.000 & -2.630 & Stationary \\
\hline dlnCaptital & -4.366 & $(0,0,0)$ & -3.750 & -3.000 & -2.630 & Stationary \\
\hline dlnLabor & -3.655 & $(\mathrm{c}, 0,0)$ & -2.518 & -1.721 & -1.323 & Stationary \\
\hline dlnPatent & -6.511 & $(0,0,0)$ & -3.750 & -3.000 & -2.630 & Stationary \\
\hline
\end{tabular}

The result is that they are all stationary on the first order difference. We can also get the same conclusion through Figure 1.

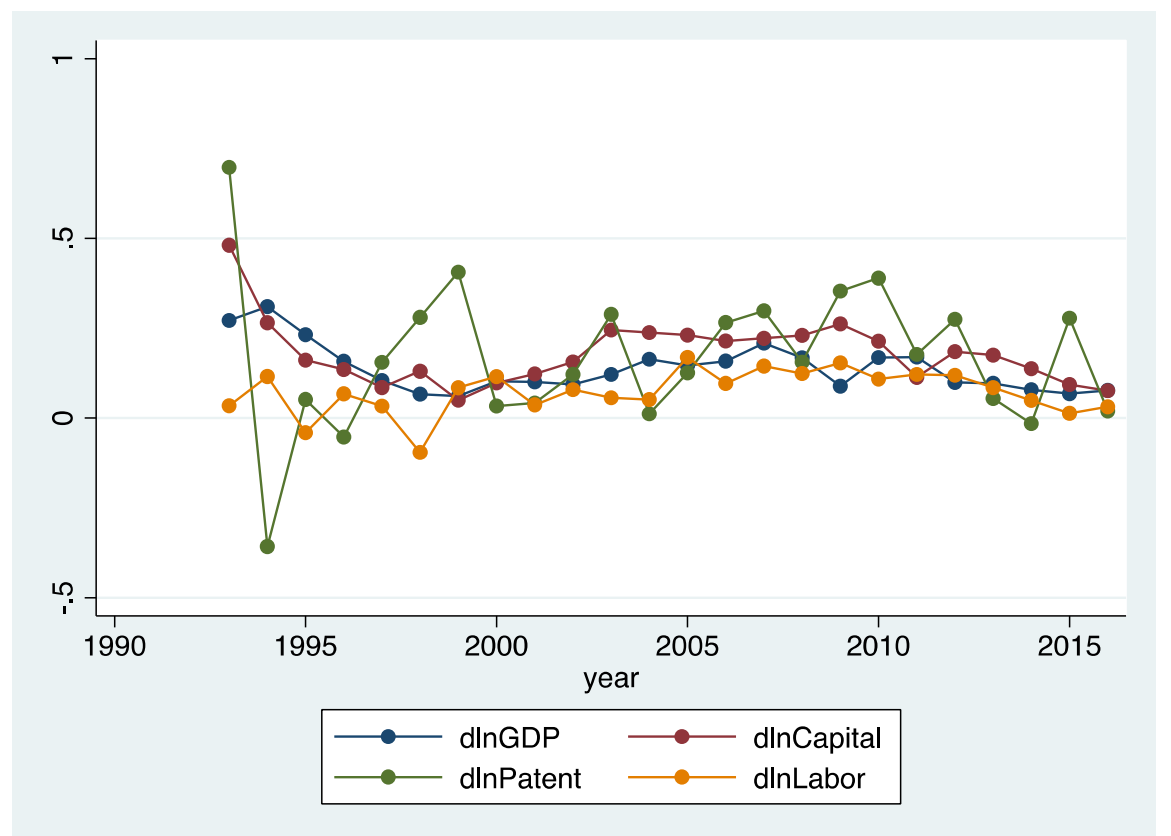

Figure 1. First-order differences of variables

We can get the following conclusion:

1. According to the result of ADF test, lnGDP is stationary, and lnCapital, lnLabor, lnPatent are unstable; 
2. The first-order difference variable dlnGDP, dlnCaptial, dlnLabor, dlnPatent are stationary. There is a cointegration relationship between variables;

3. The lnGDP, lnCapital, lnLabor, lnPatent are all first-order difference variable sequences;

4. When these variables are applied to the regression model, spurious-regression does not occur.

\subsection{Empirical Model}

Firstly, in order to test the impact of the total investment in fixed assets, the R\&D personnel fulltime equivalent and the domestic patent granted on the GDP, the linear regression model is specified for analysis in this paper as followed:

$$
\ln Y_{t}=\alpha \ln K_{t}+\beta \ln L_{t}+\gamma \ln P_{t}+\varepsilon_{t}
$$

Where, $Y_{t}$ indicates the GDP at time t, $K_{t}$ represents the total investment in fixed assets at time $\mathrm{t}, L_{t}$ states the R\&D personnel full-time equivalent at time $\mathrm{t}$, and $P_{t}$ presents the domestic patent granted at time t. Using STaTa14 to conduct a regression analysis of the GDP, the total investment in fixed assets, the R\&D personnel full-time equivalent, and the domestic patent granted.

According to the analysis results in the simple regression model (1), the t statistic of the total investment in fixed assets, and the R\&D personnel full-time equivalent input all exceeds the critical value. Moreover, the $t$ test results show a high degree of significance, indicating that the total investment in fixed assets has a significant impact on GDP growth, while the R\&D personnel fulltime equivalent has a significant negative effect on economic level. However, the $t$ statistic of the domestic patent granted is only -0.72 , representing that the impact of the domestic patent granted on the GDP is not significant. This result is explicable, for the domestic patents granted this year are difficult to be utilized immediately in production, thus have no simultaneous effect on the GDP. The $\mathrm{F}$ statistic of the regression equation passes the significance level, and the $\mathrm{R}$ square is 0.996 . The explanatory proportion of the variation is $99.6 \%$, showing that the data and the model are fitted well. However, considering that economic growth may have some continuity in time, the economic growth of the previous year may affect that of later years, so the lag of economic growth is introduced as a variable. On the one hand, we believe that technological innovation mainly influences the economic development from the aspects of the level of competitiveness and diffusion capability, and this effect may have a lag term; on the other hand, many scholars believe that the technical factors are endogenous. Therefore, this paper establishes the following dynamic model:

$$
\begin{gathered}
L n Y_{t}=\gamma_{1 t} \sum_{l=1}^{T_{1}} L n Y_{t-l}+\alpha L n K_{t}+\gamma_{2 t} \sum_{l=1}^{T_{2}} L n K_{t-l}+\beta L n L_{t}+\gamma_{3 t} \sum_{l=1}^{T_{3}} L n L_{t-l}+ \\
\gamma L n P_{t}+\gamma_{4 t} \sum_{l=1}^{T_{4}} L n P_{t-l}+\varepsilon_{t}
\end{gathered}
$$

Where $Y_{t}$ is GDP at time t, $K_{t}$ presents the total fixed asset investment at time $\mathrm{t}, L_{t}$ indicates the R\&D personnel full-time equivalent at the time $\mathrm{t}$, and $P_{t}$ represents the domestic patent granted at time t. $T_{1}, T_{2}, T_{3}$, and $T_{4}$ represent the time of lag (year),

First of all, according to the dynamic model mentioned above, we assume that each variable has sustainability. Then, we can assume that each variable has a two-year lag term, so the following model can be obtained:

$$
\begin{gathered}
L n Y_{t}=\gamma_{1 t} \sum_{l=1}^{2} \operatorname{Ln} Y_{t-l}+\alpha \operatorname{Ln} K_{t}+\gamma_{2 t} \sum_{l=1}^{2} \operatorname{Ln} K_{t-l}+\beta L n L_{t}+\gamma_{3 t} \sum_{l=1}^{2} \operatorname{Ln} L_{t-l}+\gamma \operatorname{Ln} P_{t}+ \\
\gamma_{4 t} \sum_{l=1}^{2} L n P_{t-l}+\varepsilon_{t}
\end{gathered}
$$

The analysis in the regression model (5) with two years of lag shows that: The F statistic increases to 2596.7 compared to the simple linear regression model, and the value of $\mathrm{R}$ square is still close to 1 , which indicates that fitted goodness is well. However, according to the results, the t-statistic of the GDP lagging one year, and the R\&D personnel full-time equivalent lagging two years are less than 
0.05, which means they have a significant impact on the GDP growth. However, other independent variables have no significant impact on GDP.

Therefore, it is necessary to continue to study which factors have a significant lag effect on GDP growth, and exclude those factors which are not. We retain the significant influence factors mentioned above, and also keep the data of total investment in fixed assets lagging one year. Since the impact of technological innovation on the economic level was not significant in linear regression analysis, we continue to analyze the domestic patent granted in all periods. Therefore, the following model can be obtained:

$$
L n Y_{t}=\gamma_{1 t} \operatorname{Ln} Y_{t-1}+\alpha \operatorname{LnK} K_{t}+\gamma_{2 t} \operatorname{Ln} K_{t-1}+\beta \operatorname{Ln} L_{t}+\gamma \operatorname{Ln} P_{t}+\gamma_{4 t} \operatorname{Ln} P_{t-1}+\gamma_{4 t} \operatorname{Ln} P_{t-2}+\varepsilon_{t}
$$

The analysis results in the regression model (6) with some lags changed show that, the t-statistic of the independent variable the GDP lagging one year, and the total investment in fixed assets are less than 0.05 . Thus, these variables have enormous impact on the growth of GDP. In addition, even if the F statistic: 2457.6 is still immense, and the value of $\mathrm{R}$ square is still close to 1 , the remaining independent variables have no significant effect on GDP growth.

Therefore, we continue to modify the model: this time, we only remain the independent variables that have a significant impact on GDP growth from above model and add the GDP lagging two years, the total investment in fixed assets lagging one year, the R\&D personnel full-time equivalent lagging two years and the domestic patent granted lagging two years into new model:

$$
L n Y_{t}=\gamma_{1 t} \operatorname{Ln} Y_{t-1}+\gamma_{1 t} \operatorname{Ln} Y_{t-2}+\alpha \operatorname{Ln} K_{t}+\gamma_{2 t} \operatorname{Ln} K_{t-1}+\gamma_{3 t} L n L_{t-2}+\gamma_{4 t} \operatorname{Ln} P_{t-1}+\varepsilon_{t}
$$

The analysis results in the regression model (7) with some lags changed show that, the t-statistic of the GDP lagging one year, the GDP lagging two years, and the R\&D personnel full-time equivalent lagging two years are less than 0.05 , which means these variables have significant impact on the growth of GDP. The t-statistic value of the total investment in fixed assets lagging one year, and the domestic patent granted lagging one year tend to be 0.05 . Moreover, the F statistical increases to 6328.4, which is still very significant, and the value of $\mathrm{R}$ square is still close to 1 . However, the remaining independent variables still have no significant impact on GDP growth.

Since there are still insignificant factors, we continue to optimize the model: we keep the variables that have a significant impact on GDP growth from above model, and also retain the variables with $\mathrm{t}$ statistics that tend to be 0.05 . The following model is concluded:

$$
L n Y_{t}=\gamma_{1 t} \operatorname{Ln} Y_{t-1}+\gamma_{1 t} \operatorname{Ln} Y_{t-2}+\gamma_{2 t} \operatorname{Ln} K_{t-1}+\gamma_{3 t} \operatorname{Ln} L_{t-2}+\gamma_{4 t} \operatorname{Ln} P_{t-1}+\varepsilon_{t}
$$

The model (8) analysis shows that $\mathrm{t}$ statistics of the and the GDP lagging one year, the GDP lagging two years, the R\&D personnel full-time equivalent lagging two years, the total investment in fixed assets lagging one year, and the domestic patent granted lagging one year are less than 0.05 , which means they have a significant impact on GDP growth. Moreover, the F statistic is 7046.4, and the value of $\mathrm{R}$ square is still close to 1, which indicates that the fitted goodness is well. From this model, we can conclude that the GDP lagging one year, the total investment in fixed assets lagging one year, and the domestic patent granted lagging one year have the same positive effect on GDP growth. In other words, accompanied with increase of these three variables in this year, GDP will grow next year. In the contrary, GDP lagging two years and the R\&D personnel full-time equivalent lagging two years have a significant impact on GDP growth, yet their impact is reversed. This means that last year's GDP could promote the GDP of this year, but the GDP of next year will decrease in proportion to the GDP of last year. However, from the data, we can see that the growth rate is far greater than the latter. Meanwhile, the R\&D personnel full-time equivalent lagging two years also has a negative impact on GDP. When we reduce one researcher this year, we can increase GDP in two years later. This raises a question: What is the impact of reducing researchers on the GDP for next year? In order to find the answer, we can replace the R\&D personnel full-time equivalent lagging two years with 
the R\&D personnel full-time equivalent lagging one year and keep the other independent variables unchanged to get a new model:

$$
\operatorname{Ln} Y_{t}=\gamma_{1 t} \operatorname{Ln} Y_{t-1}+\gamma_{1 t} \operatorname{Ln} Y_{t-2}+\gamma_{2 t} \operatorname{Ln} K_{t-1}+\gamma_{3 t} \operatorname{Ln} L_{t-1}+\gamma_{4 t} \operatorname{Ln} P_{t-1}+\varepsilon_{t}
$$

The analysis results of model (9) show that $t$ statistics of the GDP lagging one year, the GDP lagging two years, the R\&D personnel full-time equivalent lagging one year, the total investment in fixed assets lagging one year, and the domestic patent granted lagging one year are less than 0.05 , which means these variables have a significant impact on GDP growth. Moreover, expect the R\&D personnel full-time equivalent lagging one-year, other variables' results are not different from the previous analysis. The R\&D personnel full-time equivalent lagging one year has a negative effect on GDP. Hence, we started to doubt that whether there is a surplus of R\&D personnel input in China, or a situation that low utilization rate of researchers. From another perspective, if we reduce the number of researchers, the possibility of production of patents will be drawn down. Thus, the number of patents granted will also be declined, and the innovation ability in science and technology will descend at the same time. In the long run, this is not favorable for productivity. Furthermore, as the decreasing of productivity, GDP will go down, and the level of economic development will also suffer negative effect.

Table 5. Regression results

\begin{tabular}{|c|c|c|c|c|c|c|}
\hline VARIABLES & $\begin{array}{c}(3) \\
\operatorname{lnGDP}\end{array}$ & $\begin{array}{c}(5) \\
\ln G D P\end{array}$ & $\begin{array}{c}(6) \\
\operatorname{lnGDP}\end{array}$ & $\begin{array}{c}(7) \\
\operatorname{lnGDP}\end{array}$ & $\begin{array}{c}(8) \\
\ln G D P\end{array}$ & $\begin{array}{c}(9) \\
\operatorname{lnGDP}\end{array}$ \\
\hline L. $\operatorname{lnGDP}$ & & $\begin{array}{c}0.869^{* *} \\
(0.288)\end{array}$ & $\begin{array}{c}0.545^{* * *} \\
(0.115)\end{array}$ & $\begin{array}{c}0.785^{* * *} \\
(0.174)\end{array}$ & $\begin{array}{c}0.854 * * * \\
(0.174)\end{array}$ & $\begin{array}{c}1.118^{* * *} \\
(0.215)\end{array}$ \\
\hline L2. $\operatorname{lnGDP}$ & & $\begin{array}{c}-0.349^{*} \\
(0.168)\end{array}$ & & $\begin{array}{c}-0.272^{* *} \\
(0.110)\end{array}$ & $\begin{array}{c}-0.348^{* * *} \\
(0.102)\end{array}$ & $\begin{array}{c}-0.520^{* * *} \\
(0.132)\end{array}$ \\
\hline lnCapital & $\begin{array}{l}1.026^{* * *} \\
(0.0715)\end{array}$ & $\begin{array}{c}0.166 \\
(0.181)\end{array}$ & $\begin{array}{c}0.423 * * * \\
(0.110)\end{array}$ & $\begin{array}{c}0.147 \\
(0.0964)\end{array}$ & & \\
\hline L.lnCapital & & $\begin{array}{c}0.239 \\
(0.268)\end{array}$ & $\begin{array}{c}-0.0764 \\
(0.157)\end{array}$ & $\begin{array}{l}0.266^{*} \\
(0.139)\end{array}$ & $\begin{array}{c}0.433 * * * \\
(0.0886)\end{array}$ & $\begin{array}{c}0.368^{* * *} \\
(0.115)\end{array}$ \\
\hline L2. InCapital & & $\begin{array}{l}0.0357 \\
(0.201)\end{array}$ & & & & \\
\hline lnPatent & $\begin{array}{l}-0.0544 \\
(0.0758)\end{array}$ & $\begin{array}{l}-0.0121 \\
(0.0521)\end{array}$ & $\begin{array}{c}-0.0256 \\
(0.0640)\end{array}$ & & & \\
\hline L. lnPatent & & $\begin{array}{c}0.0888 \\
(0.0504)\end{array}$ & $\begin{array}{c}0.0324 \\
(0.0577)\end{array}$ & $\begin{array}{l}0.0523 * \\
(0.0262)\end{array}$ & $\begin{array}{c}0.0661^{* *} \\
(0.0255)\end{array}$ & $\begin{array}{c}0.0757^{* *} \\
(0.0344)\end{array}$ \\
\hline L2. lnPatent & & $\begin{array}{l}-0.0326 \\
(0.0377)\end{array}$ & $\begin{array}{c}-0.0284 \\
(0.0398)\end{array}$ & & & \\
\hline $\operatorname{lnLabor}$ & $\begin{array}{c}-0.498 * * * \\
(0.153)\end{array}$ & $\begin{array}{c}-0.0908 \\
(0.156)\end{array}$ & $\begin{array}{c}-0.0179 \\
(0.146)\end{array}$ & & & \\
\hline L.lnLabor & & $\begin{array}{l}0.0356 \\
(0.158)\end{array}$ & & & & $\begin{array}{c}-0.324 * * * \\
(0.0974)\end{array}$ \\
\hline L2. InLabor & & $\begin{array}{c}-0.250^{* *} \\
(0.112)\end{array}$ & & $\begin{array}{c}-0.261 * * * \\
(0.0683)\end{array}$ & $\begin{array}{c}-0.321 * * * \\
(0.0578)\end{array}$ & \\
\hline Constant & $\begin{array}{c}3.616^{* * *} \\
(0.156)\end{array}$ & $\begin{array}{c}1.842 * * \\
(0.778)\end{array}$ & $\begin{array}{c}1.980 * * * \\
(0.403)\end{array}$ & $\begin{array}{c}1.915^{* * *} \\
(0.354)\end{array}$ & $\begin{array}{c}1.905^{* * *} \\
(0.367)\end{array}$ & $\begin{array}{c}1.445^{* * *} \\
(0.455)\end{array}$ \\
\hline Observations & 25 & 23 & 23 & 23 & 23 & 23 \\
\hline R-squared & 0.996 & 1.000 & 0.999 & 1.000 & 1.000 & 0.999 \\
\hline $\mathrm{F}$ & $\mathrm{n} / \mathrm{a}$ & $\mathrm{n} / \mathrm{a}$ & $\mathrm{n} / \mathrm{a}$ & $\mathrm{n} / \mathrm{a}$ & $\mathrm{n} / \mathrm{a}$ & $\mathrm{n} / \mathrm{a}$ \\
\hline
\end{tabular}

Notes: a. Standard errors in parentheses;

b. $* * *, * *, *$ are representative of the significance level less than $0.01,0.05,0.1$. 


\section{Empirical Results}

The empirical results of this study are mainly as follows:

As for the Hypothesis 1: technological innovation is positively related to economic level, which means the greater the technological innovation, the better the economic level is. The empirical results can be seen from Table 4: the impact of technological innovation on the economic level is not significant.

In order to consider, the lag of technological innovation, we propose Hypothesis 2: the impact of technological innovation on the economic level has a certain lag. From Tables 8 and 9, it can be seen that, indeed, technological innovation has a lag effect on the economic level. Technological innovation has not played a role in promoting the economic level until a year after the patent was granted.

At the same time, we are also concerned about the impact of the R\&D personnel full-time equivalent on the economic level. Hence, we put forward the Hypothesis 3: the increase in the R\&D personnel full-time equivalent will also affect the economic development. Comparing model (1), model (5), and model (9), it can be concluded that the R\&D personnel full-time equivalent have the negative impact on economic level. It would not be surprising to see such a result. According to previous research conducted by other researchers, it has been found that the increase in the number of researchers has a positive impact on innovation capabilities and will only occur in OECD countries with large markets. Since China is only a developing country, the increase in the R\&D personnel fulltime equivalent is likely to have no directly positive impact on technological innovation ability, thus apparently it will not stimulate economic level. In contrary, considering about the investment of the researchers, without absorbing the benefits, there is a high possibility that increase of researchers will reduce the GDP which means drag down the economic level in current China. However, this does not mean that we should reduce the number of R\&D personnel input. Instead, in order to stimulate the future Chinese economy development, and to rely on technological progress to take a sustainable development path, we need more sophisticated researchers and outstanding research teams. When China continually develop to a better economic level, like developed OECD countries with large market, the benefit of R\&D personnel input will greatly reflect on technological innovation ability, thereby further influence China economic level. As technological advancement cannot be achieved overnight, Chinese policy-makers should not give up the investment of R\&D personnel, even if recently the increase of the $R \& D$ personnel full-time equivalent seems to have negative impact on the GDP in short term.

\section{Conclusion and Limitations}

This study is based on the theoretical model of the Cobb-Douglas production function, which selects the GDP, the R\&D personnel full-time equivalent, the total investment in fixed assets, the domestic patent granted as the variables, and uses the ADF test to examine the stationarity of these variables. Based on the stability tests, the autoregressive model AR(p) is used to study the impact of scientific and technological innovation abilities on China's economic level. The main conclusions are as follows:

First of all, economic growth is indeed proportional to the development of technological innovation, and the impact of technological innovation on the economic level has a certain lag. From the results of the models, it can be seen that the domestic patent granted lagging one year has a statistically significant positive impact on the economic level. And each time a patent is granted, the Chinese economy will grow, and this also shows that the number of patents granted has space for constant growth.

Secondly, from the overall perspective of the GDP lagging two years, the total investment in fixed assets, the total investment in fixed assets lagging one year, the domestic patent granted lagging one year, the R\&D personnel full-time equivalent and the R\&D personnel full-time equivalent lagging one year have a significant impact on the economic level. It can be seen from the empirical results that the GDP lagging one year, the total investment in fixed assets, the total investment in fixed assets 
lagging one year, and the domestic patent granted lagging one year boost economic growth. On the contrary, the GDP lagging two years and the R\&D personnel full-time equivalent and the R\&D personnel full-time equivalent lagging one year weaken the economy. However, in the long run, the latter does not necessarily weaken the economic level in reality. It is likely that the size of the Chinese market and the China's economy level qualify transforming these inputs into innovation ability. Therefore, at the stage of China's economic level, inputting more researchers will decline the GDP.

The main limitation of this paper: although the data of the domestic patent granted is a good representation of the patents obtained in China, some patents may not be applied domestically. Moreover, some companies and organizations may not only use domestic patents in production, but also may introduce some foreign patents to make their companies more efficient and productive. Since these variables are not included in our model, China's technological innovation ability may be underestimated. Thereby the impact of innovation on China's economic progress may be also underestimated.

\section{References}

[1]. Donghyun Oh, Almas Heshmati \& Hans Lööf (2012) Technical change and total factor productivity growth for Swedish manufacturing and service industries, Applied Economics, 44:18, 2373-2391.

[2]. Gene M. Grossman, Elhanan Helpman (1994) Endogenous Innovation in the Theory of Growth, Journal of Economic Perspectives, 8(1), 23-44.

[3]. Hulya Ulku (2007) R\&D, innovation and output: evidence from OECD and nonOECD countries, Applied Economics, 39:3, 291-307.

[4]. Miguel-Ángel Galindo, María Teresa Méndez (2014), Entrepreneurship, economic growth, and innovation: Are feedback effects at work? Journal of Business Research, 67(2014) 835-828.

[5]. Rudra P. Pradhan, Mak B. Arvin, John H. Hall \& Mahendhiran Nair (2016) Innovation, financial development and economic growth in Eurozone countries, Applied Economics Letters, 23:16, 1141-1144. 